\title{
Introduction to and Perspective on the Colloquium
}

\author{
Robert J. Dufault \\ Clemson University, Coastal Research and Education Center, \\ 2865 Savannah Highway, Charleston, SC 29414
}

\begin{abstract}
Various new horticultural crops have been established in the last 25 years that have made significant economic impacts in different localities. For example, the first commercial kiwi fruit planting in California was made in 1962, and by 1984 , the area had grown to 1600 hectares (CAST, 1984). There has been increased use of new and nontraditional vegetables in the United States. Recent immigrants from the Caribbean, Central America, and Southeast Asia brought their crops and tastes with them, and these are influencing the American diet. For example, there is a sizable production of specialty vegetables for domestic consumption and export that has developed in southern Florida. New crops include boniato (Ipomea batatas L. Lam.), calabaza (Cucurbita moschata Duch. ex. Lam.), malanga (Xanthosoma caracu Koch and Bouche), cassava (yuca or tapioca) (Manihot esculenta Crantz). Minor specialty crops, grown on relatively few hectares, are produced in California, Hawaii, Florida, and New Jersey and their value amounts to millions of dollars annually. A similar potential for providing ethnic vegetables exists in other locations in the United States. There are small enclaves of people of strong ethic tastes throughout the United States. Vegetables that may have been traditional in the diet of Latin Americans or in the Caribbean have only been recently introduced into the United States. These new crops could be grown and marketed locally. Unfortunately, local producers of traditional vegetables often are unaware of the market available to them for ethnic crops.

Horticultural crops supply a wide array of commodities valued at $\$ 16$ billion annually (CAST, 1984). These include landscaping and ornamental plants, as well as the raw materials of the canning, freezing, dehydrating, fresh-market fruit, and vegetable industries. Worldwide, fruits and vegetables represent one-third of the total value of all crops. Horticultural products are significant items in U.S. exports and imports. The potential for increased U.S. export
\end{abstract}

of horticultural crops is promising and for some farmers may present future opportunities. At present, the volume of U.S. imports of fresh vegetables has increased significantly from 1970 to 1986, growing $\approx 4 \%$ yearly (U.S. Dept. Agr., 1988). Gains came from asparagus, broccoli, cauliflower, celery, sweet corn, onions, and honeydew melons. The majority of fresh vegetable imports come from Mexico during the winter months when U.S. supplies are low. Innovative technology must be developed to produce domestically some of these imported crops to decrease the U.S. farmers' economic plight. Exports of U.S. produce increased only 2\% from 1970 to 1986 (U.S. Dept. Agr., 1988); however, exports in the late 1980s steadily declined. About $92 \%$ of the exported products went to Canada, and the future outlook has been termed "favorable" for increased exports to Canada, as its demand for quality and diverse produce parallels that of consumers in the United States.

Farmers facing the economic crunch of the 1980s are also looking to nonfood commodities, where markets exist. Cut flowers are an alternative to consider. Americans are beginning to use cut flowers more than ever before. The cut flower industry traditionally has been characterized by large imports with domestic production concentrated in a few states. The majority of present U.S. imports comes from Colombia, Mexico, and the Netherlands (U.S. Dept. Agr., 1988). In spite of this, the United States does have market niches in the case of many crops, such as roses. Opportunities exist for niches to be carved out for the production of a wide range of other cut flowers.

Foreign markets may be out of the reach of small farmers who are interested in producing and marketing quality produce locally. Areas within the United States, such as the Midwest and Southeast, are capable of producing quality produce. Competition with the major vegetable producing states of California, Texas, and Florida 
heightens frustration for small growers in other geographical areas. Credible information is needed to provide direction to these small growers. However, no matter which alternative is taken, it is necessary to coordinate the production of new crops by farmers to provide the quantities and quality that the market demands (CAST, 1984). Without this coordination, buyers face uncertain supplies and growers face uncertain markets. These uncertainties pose unacceptable risks for both.

Viable strategies to counteract the depression in agricultural sectors require attention from specialists in various disciplines, including agronomy, horticulture, plant pathology, entomology, weed science, agricultural economics, agricultural engineering, product processing and development, and marketing. Challenges are omnipresent for those in university extension and research; however, the funding to fuel research and extension alternative crops work may not always be available. There has been little growth in federal support for agricultural research since 1975 compared with the $3.8 \%$ annual growth rate from 1939 through 1965 (Batie and Healy, 1983). Therefore, alternate approaches to problem solving and financing must be taken. The outlook for federal funding seems gloomy. The buying power of the federal appropriations for Agricultural Research and Extension base programs declined by $20 \%$ over the last decade (Natl. Assn. State Univ. Land Grant Colleges, 1989).
The situation that is confronting all of us in Agricultural Research and Extension is outlined in subsequent contributions. There have been and are organized formal research and development programs to provide new horticultural and economic information on production and economic information on production and marketing of alternative crops to help alleviate some of the stresses placed on the farmers. The intent of this colloquium is to examine, compare, and contrast the approaches of various alternative programs to: 1) identify useful alternative crops; 2) finance and initiate research activities; 3) implement research findings; and 4) judge the impact of research and development programs. Critical considerations for the production of ethnic crops and field cut flowers are also explored.

\section{Literature Cited}

Batie, S.S. and R.G. Healy. 1983. The future of American agriculture. Sci. Amer. 248:45-53.

Council on Agricultural and Science Technology (CAST). 1984. Development of new crops: needs, procedures. strategies. and options. Rpt. 102. CAST, Ames, Iowa.

National Association of State Universities and Land Grant Colleges. 1989. Report by the FY90 Budget Committee of the Division of Agriculture. March ed.

U.S. Dept. of Agriculture. 1988. Vegetables and specialities: Situation and outlook report. Econ. Res. Serv. TVS-244. 